\title{
Editorial
}

\section{Health of migrant worker during covid-19 pandemic- some insights}

\author{
Shweta Gangurde ${ }^{1, *}$, Nirankush Borah ${ }^{1}$ \\ ${ }^{1}$ Dept. of Community Medicine, Dr. D.Y Patil Medical College \& Research Centre, Pune, Maharashtra, India
}

\section{A R T I C L E I N F O}

Article history:

Received 15-06-2021

Accepted 24-06-2021

Available online 27-07-2021
(C) This is an open access article distributed under the terms of the Creative Commons Attribution License (https://creativecommons.org/licenses/by/4.0/) which permits unrestricted use, distribution, and reproduction in any medium, provided the original author and source are credited.

\section{Dear Sir,}

2020 has mark the start of a new era or better known as the COVID times. With a population of around 1.38 billion, migration within states in respect to job or business was a normal affair until the second quarter of 2020 when lockdown restrictions were implemented. No one anticipated that measures to contain the virus will have an ill effect too. The migrant workers were among those who suffered a lot. With the growing stigma among people regarding the virus the acceptance of the public towards the needy was compromised. None offered shelter to the migrant workers, they lost their jobs, were deprived of the basic necessities to survive. They were all stuck at their places of work unable to get back to their native place. Panic was quite common among the daily wage earners. Migrant workers in India tend to live and work in Megacities in crowded conditions that do not permit Social distancing, putting them at higher risk of getting infected. ${ }^{1}$ At onset of COVID-19 pandemic, almost all countries in the world enforced Coronavirus related travel restrictions and border restrictions. $^{2}$ The sudden lockdown in India left lakhs of migrant workers stranded on the roads, without any jobs, income, food and accommodation. ${ }^{1}$ As Lockdown settled down, Migrant workers were seen struggling the most due to loss of their job followed by no money and place to stay which made them move back to their native place.

\footnotetext{
* Corresponding author.

E-mail address: shwt.gangurde@gmail.com (S. Gangurde).
}

In India as migration is primarily for survival and poverty is a major inducing factor behind migration, migrant laborers ran out of resources within a few days of the lockdown promulgation. Since public convey was absent migrants opted for unsafe and not routine ways of transport majority of times on bare foot with half-filled stomach. Some died ambulating, some died in accidents, some died of hunger, and some even committed suicide. ${ }^{1}$

No one except, some voluntary organizations and some benevolent people in individual capacity came for their rescue. Migrant labourers became an alien in their land. ${ }^{3}$

According to the World Economic Situation and Prospects as of mid-2021, this global crisis has aggravated poverty and intra-country disparities and it will have long term effect on labour markets and tedious efforts will be required to reverse inequalities. ${ }^{4}$

National Human Rights Commission (NHRC) study on the social security and health rights of migrant workers says that this politicaly unseen segment of the society doesn't get access to even elementary amenities and they are looked upon as expatriates or second-class residents in the host states. $^{5}$

Internal migrant workers feel marked anxieties and uncertainties due to various apprehensions in COVID 19 pandemic, and require psycho-social support. ${ }^{6}$ The continuous reverse migration of millions of migrant workers to their native villages can prove to be unfavourable for the mental health and rural India may be particularly vulnerable to suicide in near future due to the hefty economic 
burden of unemployed migrant workers. Indian industries, had about 100 million internal migrant workers, having a sizeable impact on the economics of India. They are already susceptible to adverse psychological consequences of numerous stresses, generated through interfaces of various factors, not limited to chronic poverty, malnutrition, cultural bereavement, loss of religious practices and social protection systems, changes in identity, substance abuse and poor access to healthcare in addition to the poor living conditions and financial constraints and the pandemic just adds to it. ${ }^{7}$

Efforts were made by central and state government to address migrant laborers' issues by keeping them at shelter homes and providing them food. However, how much this is aiding the migrants is not very well known. Every day there are media reports of migrant workers travelling to their native places far off from their current location by walking or by cycling. Many have faced death after reaching their destination or during the course of their journey. ${ }^{8}$

Study done by Kumar $\mathrm{K}$ et al showed that out of 98 migrant labours about one-fifth of the participants screened positive for depression only. Nearly half $(51 \%)$ of participants screened positive for both anxiety and depression. Overall, nearly a quarter $(73.5 \%)$ were screened positive for at least one psychiatric illness. ${ }^{9}$

\section{Conclusion}

The pandemic has made the streets numb, humanity questionable, declining resources, chaos in terms of availability of beds for the needy, plight of daily wage earners and migrants and hope to be back again into precovid times. Mentally the migrant workers were exhausted with no options left for them to explore. The feeling of being deprived from their loved ones in that hour of pandemic created panic and fear in them. Psychological counselling, stress management technique was the need of the hour. Recommendation for proper diet and the importance of Social-distancing and hand hygiene should be highlighted Social protection of migrant workers should be an important intervention by state.

\section{Source of Funding}

Nil.

\section{Conflicts of Interest}

There are no conflicts of interest.

\section{References}

1. Suresh R, James J, Balraju SJR. Migrant Workers at Crossroads-The Covid-19 Pandemic and the Migrant Experience in India. Soc Work Public Health. 2020;35(7):633-43. 601:0. 108010371018.2020. 80855

2. Ullah A, Nawaz F, Chattoraj D. Locked up under lockdown: The COVID-19 pandemic and the migrant population. Soc Sci Humanit Open. 2021;3(1):100126. do1:10.1016/].ssaho.2021.100126.

3. Kumar S, Choudhury S. Migrant workers and human rights: A critical study on India's COVID-19 lockdown policy. 2021;3(1). doi:10.1016/j.ssaho.2021.100130.

4. Available from: https://www.un.org/en/academic-impact/researchingimpact-pandemic-internal-migrant-workers-india.

5. Available from: https://www.hindustantimes.com/india-news/migrantworkers-treated-as-outsiders-says-nhrc-study-101618787510990. html.

6. Available from: https://www.mohfw.gov.in/pdf/ RevisedPsychosocialissuesofmigrantsCOVID19.pdf.

7. Choudhari R. COVID 19 pandemic: Mental health challenges of internal migrant workers of India. Asian J Psychiatry. 2020;54:102254. do1:10.1016/].ajp.2020.102254.

8. Staff S. 2020. Covid-19: At Least 22 Migrants Die While Trying to Get Home During Lockdown [WWW Document] Scroll.in. Available from: https://scroll.in/latest/957570/covid-19-lockdown-man-collapsesdies-halfway-while-walking-home-300-km-away-from-delhi.

9. Kumar K, Mehra A, Sahoo S, RNehra, Grover S. The psychological impact of COVID-19 pandemic and lockdown on the migrant workers: A cross-sectional survey. Asian J Psychiatry. 2020;53:102252. do1:10.1016/].ajp.2020.102252.

\section{Author biography}

Shweta Gangurde, Post Graduate Resident

Nirankush Borah, Post Graduate Resident

Cite this article: Gangurde S, Borah N. Health of migrant worker during covid-19 pandemic- some insights. J Community Health Manag 2021;8(2):58-59. 